important strides with its information technology strategy to bring order out of chaos. It now needs to bring the cutting edge of evidence to decision making in this area.

LIAM J DONALDSON

Professor of applied epidemiology

Department of Epidemiology and Public Health,

University of Newcastle upon Tyne,

Newcastle upon Tyne NE2 $4 \mathrm{HH}$

1 Sand T, Rinde E. Telemedicine: still waiting for users. Lancet 1995;346(suppl):24 .
2 Lock C. What value do computers provide to NHS hospitals? BMF 1996;312:1407-10.

3 Willcocks L Information technology in public sector settings: towards effective systems. InterWillcocks L. Information technology in public sector setting:
national fournal of Public Sector Management 1989:2:15-29.

4 Brittain JM, MacDougall J. Information as a resource in the National Health Service. International Yournal of Information Management 1995;15:127-33.

5 Collins T. The wasted millions. Computer Weekly 1992;May 7:32-4.

6 Haughton E. BMA slams hospitals' trial network. Computer Weekly 1989 October 12:8

7 Information Management Group. An information management and technology strategy for the NHS in England. Leeds: NHS Management Executive, 1992.

8 Sullivan F, Mitchell E. Has general practitioner computing made a difference to patient care? A systematic review of published reports. BMF 1995;311:848-52.

9 Powell P. Information technology evaluation: is it different? $f$ Opl Res Soc 1992;43:29-42.

10 Information Management Group. Substantial information management and technology investments. Leeds: NHS Management Executive, 1994.

\title{
Going home
}

\section{The first few weeks after a heart attack}

Early discharge after myocardial infarction avoids the dangers of prolonged immobilisation, but it often leaves the patient bewildered, depressed, and anxious. ${ }^{1}$ Many survivors and their partners will say that the period immediately after discharge was the most difficult after their heart attack. ${ }^{23}$ Sudden death is a substantial possibility in the first few weeks at home, ${ }^{4}$ yet commonly this stage in the recovery receives little attention from health professionals. and most patients receive no medical help during their first few weeks at home (unpublished data).

If general practitioners visit soon after discharge they can do a great deal to help. They can confirm the diagnosis and discuss the nature of the disease. Much of this will have been done in hospital, but the patient may not have understood or remembered all that he or she has been told. ${ }^{5} \mathrm{~A}$ booklet in language suitable for the individual patient should help. ${ }^{6}$ The general practitioner should check that the patient understands the importance of modifying risk factors to avoid future coronary problems. The patient should also be told to expect and ignore niggling left sided chest pain, light headedness, and occasional "missed" beats. Questions should also be asked about less common but potentially serious symptoms which warrant urgent referral to hospital. These are angina on minor exertion, breathlessness with light exercise or in bed, and rapid palpitations, particularly if accompanied by faintness.

The next step is to review the drugs currently being taken, including the dose, duration, purpose, and possible side effects. Nearly all patients should be taking aspirin, ${ }^{7}$ and many will be taking $\beta$ blockers and experiencing some of their common side effects. An increasing number will be taking an angiotensin converting enzyme inhibitor ${ }^{8}$ and will need their blood pressure and renal function monitored while the dose is gradually increased to the optimum level. Patients given glyceryl trinitrate tablets or a spray should have written instructions on their appropriate use.

Patients are often anxious about physical activity and how rapidly to increase it. Here the advice must be tailored to the individual: what is right for a 35 year old man who has just recovered from a small infarct will be very different from that for a man aged 80 already disabled by other diseases to which has been added substantial cardiac damage. If the local district hospital offers an exercise based rehabilitation programme the general practitioner should strongly encourage the patient to join. ${ }^{9}$ In the absence of such a programme many general practitioners may find the Heart Manual useful. ${ }^{10}{ }^{11}$

Advice will also be needed on specific topics including sexual intercourse, driving, and flying on commercial airlines. Sex within a week or two of arriving home is unlikely to cause any problems unless it is with an unfamiliar partner. ${ }^{12}$ The Driving Vehicle Licence Authority recommends that people should not drive for four weeks after an infarct, but it does not need to be informed of the attack unless the patient has heart failure, dangerous arrhythmias, or angina precipitated by driving ${ }^{13}$. Patients should inform their insurance company. Air travel is best delayed for six weeks after the attack, or longer in patients who have heart failure or severe angina.

Most hospitals arrange to see patients who have had infarcts at least once after discharge-usually at about four to six weeks. Typically, patients will have an exercise test at this stage, and those whose result is negative are usually discharged without a follow up appointment. Abnormal results on exercise testing will require further assessment and may lead to coronary angiography and perhaps to revascularisation. Patients who have made an uncomplicated recovery and have sedentary jobs are fit to be back at work within six weeks, but those with manual jobs are commonly advised to stay away for 8-12 weeks.

The aftercare of patients with infarcts also puts an onus on the hospital. A discharge summary sent out at the time that the patient goes home should include the degree of risk so that patients at high risk can be monitored especially carefully. Three factors increase risk. These are extensive left ventricular damage $^{414}{ }^{15}$ such patients should usually be discharged taking an angiotensin converting enzyme inhibitor ${ }^{10}$; residual reversible ischaemia as evidenced by angina ${ }^{14}$; and frequent ventricular ectopic beats. ${ }^{15}$

The care of and outlook for patients recovering from infarcts could be improved. Cardiologists in district hospitals could coordinate their aftercare; general practitioners could visit patients soon after discharge; and follow up in outpatients could be with a doctor of at least registrar status, with encouragement to attend the rehabilitation programme. Finally, general practitioners could organise a follow up programme that would check on and treat risk factors, review drug treatment, and monitor new symptoms. Too few patients receive treatment of this quality.

H J N BETHELL Chairman

Advisory Committee on Secondary Prevention and Rehabilitation,

Coronary Prevention Group,

London School of Hygiene and Tropical Medicine,

London WC1E 7DB

1 Delliapiani AW, Cay EL, Philip AE, Colling WA, Donaldson RJ, McCormack P. Anxiety after a heart attack. Br Heart f 1976:38:1785-9.

Wishnie HA, Hackett TP, Cassem NH. Psychological hazards of convalescence following myocardial infarction. $¥ A M A$ 1971;215:1292-6.

3 Bedsworth J, Molen M. Psychological stress in spouses of patients of patients with myocardial infarction. Heart Lung 1982;11:450-3.

4 Stevenson R, Ranjadayalan K, Wilkinson P, Roberts R, Timmis AD. Short and long term prognosis of acute myocardial infarction since the introduction of thrombolysis. BMF 1993;307:344-53.

5 Lewin B, Robertson IH, Cay EL, Irving JB, Campbell M. Effects of self-help post-myocardial infarction rehabilitation on psychological adjustment and use of health services. Lancet 1992;339:1039-40.

6 Lewin B. The heart manual. Edinburgh: Edinburgh Health Care NHS Trust, 1994

7 Ley P. A method for increasing patient recall of information presented by doctors. Psychol Med 1973;3:217-20.

8 Raleigh EH, Odtohan BC. The effect of a cardiac teaching program on patient rehabilitation. Heart Lung 1987;16:311-7. 
9 Antiplatelet Trialists' Collaboration. Collaborative overview of randomised trials of antiplatelet herapy - I: prevention of death, myocardial infarction and stroke by prolonged antiplatele therapy in various categories of patients. BMF 1994;308:81-106.

10 SAVE Investigators. Effect of captopril on mortality and morbidity in patients with left ventricular dysfunction after myocardial infarction. N Engl f Med 1992;327:669-77.

11 Horgan JH, Bethell HJN, Carson PHM, Davidson C, Julian DG, Mayou RA, et al. British Cardiac Society working party report on cardiac rehabilitation. Br Heart J 1992;67:412-8.

12 Ueno M. The so-called coition death. Fapanese fournal of Legal Medicine 1963;17:333-7.
13 Taylor JF Medical aspects of fimess to drive. London: Medical Commission on Accident Prevention, 1995 .

14 Theroux P, Waters DD, Haphen C, Debaisieux JC, Mizgala HF. Prognostic value of exercise testing soon after myocardial infarction. N Engl F Med 1979;301:341-5.

15 Kostis JB, Byington R, Friedman LM, Goldstein S, Furberg C. Prognostic significance of ventricular ectopic activity in survivors of acute myocardial infarction. $\mathcal{f} \mathrm{Am}$ Coll Cardiol 1987;10:231-42.

\title{
Mortality among second generation Irish in England and Wales
}

\author{
Poorer health is not fully explained by continuing socioeconomic disadvantage
}

People born in Ireland make up the largest immigrant group in England and Wales and have been found in earlier studies to have poorer health than all other immigrant groups. ${ }^{12}$ The paper in this issue by Harding and Balarajan ( $p$ 1389)shows that mortality among second generation Irish - those born in England and Wales with one or both parents born in the Republic of Ireland-is significantly higher than overall mortality for all causes and for most major causes of death. ${ }^{3}$ It is important to understand this continuing health disadvantage among the children of Irish immigrants.

The history of immigration from Ireland has been a long and sometimes dramatic one. The social, economic, and demographic characteristics of the first generation of Irish settlers undoubtedly influenced their patterns of morbidity and mortality. They could also have influenced the magnitude and type of mortality of the second generation.

Emigration from Ireland has occurred at least since the Act of Union in 1800 (in which Ireland became part of the United Kingdom), the rate of emigration depending on the degree of economic hardship and population pressure at home and the demand for labour and service in Britain. When potato blight destroyed the crop for four successive years in 1845-8, causing the Great Famine, the population of Ireland is estimated to have fallen by as much as one fifth, with possibly as many dying as emigrating. The population stood at 8.2 million in 1841 , but was reduced to 6.6 million in $1851 .{ }^{4}$ Of those who emigrated, between one in five and one in seven settled in England and Wales. However, the first wave of large scale immigration started earlier, in 1841, when there were already 290000 people born in Ireland living in England and Wales. ${ }^{5}$ By 1861, that number had swollen to over 600000 representing over 1 in 40 of the population of England and Wales. ${ }^{6}$

Although the Irish immigrants were of poorer social and economic standing than the general population, and more likely to live in lower quality housing in overcrowded urban areas, they did come from a variety of social and economic backgrounds. Some secured skilled and responsible jobs and achieved a good standard of living. ${ }^{78}$ Also, although Irish immigrants were overrepresented in the larger industrial towns, cities, and ports, between 1851 and 1871 smaller towns increased their share of the total Irish population. ${ }^{8}$ In the remaining decades of the 19 th century, the pace of Irish immigration generally declined ${ }^{4}$ and the proportion of people born in Ireland fell, aided by onward migration to other countries.

In the early part of this century the rate of immigration was relatively low, although it increased in the late 1920 s and early 1930s. After the outbreak of the second world war, Irish workers were increasingly recruited to help in the war effort, and played an important part in postwar reconstruction and development. Although the 1960s witnessed large scale immigration into England and Wales from the West Indies and the Indian subcontinent, by the time of the 1971 census it was still Irish people - those born in the republic-who constituted the largest single immigrant group from outside Britain, numbering about $650000 .^{9}$ In addition, there were over one million second generation Irish and no doubt many residents of more distant Irish ancestry.

The population studied by Harding and Balarajan comprises a $1 \%$ sample of people who were second generation Irish aged 15 or over in England and Wales in 1971 and who died in the subsequent 18 years. The bulk of those who died are likely to have had parents who were born between 1870 and 1930 in the Republic of Ireland. Compared with their English-born counterparts, a disproportionately large number of men would have been in manual occupations-in industry and construction-while the women would have been in the more menial service occupations, although Irish women were also overrepresented in the lower ranks of the professions such as nursing and teaching. Hence the socioeconomic position of the first generation Irish immigrants would have predisposed them towards higher levels of mortality. Mortality in the areas in which they were concentrated (London, Liverpool, Manchester, Leeds, Birmingham, Newcastle, and other large cities) would also have been well above average. This partial information offers a possible ecological explanation for the raised mortality among the first generation Irish, which has been observed again in recent decades. ${ }^{2}$

Overall, the mortality of first generation Irish people-those born in Northern Ireland and the republic-exceeds that of all residents of England and Wales by about $30 \%$ for men and $20 \%$ for women . Excess mortality is found for most causes of death, but it is particularly high for tuberculosis, diseases of the respiratory and digestive systems, certain malignant neoplasms, and for external causes of injuries and poisonings (accidents, poisonings, and violence).

The pattern of morbidity is generally similar. Rates of self reported limiting long term illness are generally higher for those born in Northern Ireland and the Republic than for all residents of England and Wales. Patients' consulting rates for all illnesses derived from the fourth national study on morbidity statistics in general practice also show a corresponding differential (unpublished data).The patients' consulting rates for those born in Northern Ireland and the republic are generally higher for diseases of the circulatory, respiratory, digestive, musculoskeletal, and nervous systems. In addition, there is a wider differential in rates of consulting for mental disorders and injuries and poisonings between men of working age born in Ireland and all men of working age resident in England and Wales.

Certain common characteristics are apparent. A feature of immigrant groups is that their patterns of health and mortality tend to converge with those of their adopted country, if not within one generation, then within two. Comparing mortality rates in the countries of origin and destination can provide clues to the aetiology of disease. The apparent persistence of excess mortality into the second generation for those of Irish parentage suggests that some important elements of being 